\title{
REVIEW
}

\section{Physiological and ecological responses of crustaceans to ocean acidification}

\author{
N. M. Whiteley* \\ School of Biological Sciences, College of Natural Sciences, Bangor University, Bangor, Gwynedd LL57 2UW, UK
}

\begin{abstract}
The sensitivity of marine crustaceans to ocean acidification is poorly understood, but can be assessed by combining data from physiological and ecological studies. The species most at risk are exclusively marine and have limited physiological capacities to adjust to environmental change. They are poor iono- and osmoregulators and have limited abilities to compensate for acid-base disturbances. The problems are compounded in slow-moving, relatively inactive species because they have low circulating protein levels and low buffering capacities. Species living in low-energy environments, such as deep-sea and polar habitats, are particularly vulnerable, because they are metabolically limited with respect to environmental change. Elevated $\mathrm{pCO}_{2}$ levels in seawater, such as those predicted for the year 2300, are known to have diverse effects on calcification rate, little effect on egg production and a negative effect on growth rate and moulting frequency in marine crustacean species. At these levels, embryonic development is negatively impacted, but larval and juvenile stages do not appear to be affected, unless the changes in $\mathrm{pCO}_{2}$ are accompanied by rising temperatures. Overall, marine crustaceans are broadly tolerant to the seawater $\mathrm{pCO}_{2}$ levels expected by 2100 and 2300, but only in the medium-term (weeks) and only in the more adaptable species. The reductions in growth rate are of concern, as these changes could affect species survival, distribution and abundance. Studies are urgently needed to evaluate whether the patterns of vulnerability identified here in crustaceans will still be relevant after long-term (months) exposure to the relevant $\mathrm{pCO}_{2}$ levels, in combination with changes in other environmental factors.
\end{abstract}

KEY WORDS: Climate change - Crustacean · Calcification · Development · Growth · Marine • Ocean acidification $\cdot$ Reproduction

Resale or republication not permitted without written consent of the publisher

\section{INTRODUCTION}

Acidification of the world's oceans by the absorption of anthropogenic $\mathrm{CO}_{2}$ is causing so much concern that it is gaining recognition alongside climate change as 'the other $\mathrm{CO}_{2}$ problem' (Doney et al. 2009). Global atmospheric $\mathrm{pCO}_{2}$ levels have increased from 0.03 to $0.04 \mathrm{kPa}$ since pre-industrial times and are predicted to reach $\sim 0.08 \mathrm{kPa}$ by 2100 ('business-as-usual' $\mathrm{CO}_{2}$ emission scenario, Houghton et al. 2001). More than a third of the atmospheric $\mathrm{CO}_{2}$ emitted into the atmosphere since the beginning of the industrial revolution has been absorbed by the oceans, resulting in an alteration in the seawater carbonate system to give a $30 \%$ increase in $\mathrm{H}^{+}$concentrations (0.1 pH unit) and a $16 \%$ reduction in carbonate ion concentrations (Feely et al.
2004, Fabry et al. 2008). As ocean acidification is happening at a rate that outstrips the neutralising action of sedimentary antacids, it is predicted that the continued release of fossil-fuel $\mathrm{CO}_{2}$ into the atmosphere will reduce ocean $\mathrm{pH}$ levels from present day levels of 8.1 to 7.8-7.7 by the end of the century (Orr et al. 2005), and to $\mathrm{pH} 7.4$ by 2300 if atmospheric $\mathrm{CO}_{2}$ reaches $0.20 \mathrm{kPa}$ (Caldeira \& Wickett 2003). Critically, pH levels will be lower than those experienced for the past 25 million yr (Royal Society Report 2005, Widdicombe \& Spicer 2008).

The biological effects of ocean acidification are still far from clear, although interest in this area has intensified considerably over the past $7 \mathrm{yr}$ (Pörtner et al. 2004, Fabry et al. 2008, Pörtner 2008, Przeslawski et al. 2008, Doney et al. 2009). Over this time period, there 
has been a tendency to concentrate on marine taxa considered to be the most vulnerable to ocean acidification, such as cnidarians, echinoderms and molluscs. These taxonomic groups have received the most attention because calcification of the external shells and skeletons is influenced by the changes in seawater $\mathrm{pCO}_{2}, \mathrm{pH}$ and $\left[\mathrm{CO}_{3}{ }^{2-}\right]$ associated with ocean acidification. In extreme cases, for instance, elevated seawater $\mathrm{CO}_{2}$ can cause dissolution of the calcified skeleton and reduce calcification rates (e.g. Gattuso et al. 1998, Langdon et al. 2000, Kleypas et al. 2006, Gazeau et al. 2007). Physiological studies have also revealed that echinoderms and bivalve molluscs are likely to be the most vulnerable to ocean acidification because they are poor iono-regulators and show little ability to buffer the acidifying effects of elevated $\mathrm{CO}_{2}$ in their body compartments (Fabry et al. 2008, Widdicombe \& Spicer 2008, Doney et al. 2009, Melzner et al. 2009, Dupont et al. 2010). The resulting consequences can be far reaching as acidification of body compartments can lead to metabolic depression (Michaelidis et al. 2005, Miles et al. 2007, Rosa \& Seibel 2008), a reduction in energy stores (Langenbuch \& Pörtner 2002, 2003) and a reduction in growth rate (Michaelidis et al. 2005, Beniash et al. 2010). Physiological studies can therefore be used to explain species-related differences in sensitivity, which, in turn, can be used to predict changes in individual performance and survival. Consequently, physiological changes have been used in the recent past to inform on the ecological effects of ocean acidification (Fabry et al. 2008, Guinotte \& Fabry 2008, Widdicombe \& Spicer 2008, Dupont et al. 2010). Over the past 7 yr there has been a concerted effort to switch attention from short-term acute exposures (hours to days) to extremely high $\mathrm{pCO}_{2}$ levels (hypercapnia) to more relevant $\mathrm{pCO}_{2}$ over longer time intervals, such as medium-term (weeks) to long-term exposure (months) (Fabry et al. 2008, Widdicombe \& Spicer 2008, Doney et al. 2009). There has also been a move towards studies based on community mesocosms in order to examine changes in biodiversity and community structure (Widdicombe et al. 2009, Hale et al. 2011). In addition, there is a growing realisation that concomitant changes in other environmental variables, such as temperature, salinity and oxygen, may also modify responses to ocean acidification and further decrease chances of survival (Fabry et al. 2008, Widdicombe \& Spicer 2008, Findlay et al. 2010a,b). Finally, there has been an increasing interest in the survival of early developmental and reproductive stages, which are likely to be the most vulnerable to ocean acidification (Dupont et al. 2008, 2010, Kurihara 2008).

Collectively, these approaches have demonstrated that the ability to tolerate ocean acidification is species specific and varies within phyla and between closely related species (Doney et al. 2009, Melzner et al. 2009, Hale et al. 2011). As we learn more about the longterm effects of ocean acidification on the physiology and ecology of marine invertebrates, it is becoming apparent that even those species generally tolerant of ocean acidification are under threat. Medium- to longterm compensation for projected ocean acidification conditions could prove to be energetically costly. Examples already exist in the literature to indicate that energy can be diverted away from key biological processes such as growth and reproduction towards compensatory responses (e.g. Wood et al. 2008, Beniash et al. 2010). On the other hand, certain species may be more resilient than once thought because they can acclimatise or adapt to the changes. Clearly, we need to examine the effects of ocean acidification on a wider range of species from different taxa to get a better idea of the possible effects of the projected climate change conditions on marine species, communities and ecosystems. Valuable lessons could be learned from taxa that have been largely overlooked, especially those that are considered to be tolerant of ocean acidification, such as crustaceans.

The effects of oceanic acidification on marine crustaceans have received some attention, however, the studies are disparate and have been conducted on widely divergent species for varying lengths of time at different $\mathrm{pCO}_{2}$ levels. Our general lack of knowledge on the potential effects of ocean acidification on marine crustaceans is surprising because most crustaceans are characterised by a mineralised chitinous exoskeleton, which could be affected by changes in seawater carbonate chemistry. Crustaceans are also ecologically and economically important. In addition, there is a wealth of background physiological information that can be used to explain differing sensitivities to ocean acidification. If crustacean species are adversely affected by ocean acidification, then this could have farreaching ecological consequences, as crustaceans are primary and secondary consumers and an important food source for higher trophic levels. For instance, crustacean species form the bulk of the zooplankton and can be present in vast numbers, either as pelagic larvae or as adults. Total biomass can reach impressive levels, as shown in the Southern Ocean where Antarctic krill Euphausia superba reach a total biomass of 133 million tonnes at any one time (Atkinson et al. 2009). Any adverse effects could also have an impact on the shellfish industry, as several decapod species (lobsters, crabs, prawns and shrimps) can be cultured or harvested for food or bait. Shellfish culture, which includes both crustaceans and bivalves, has increased in importance in recent years, reaching $20 \%$ of the global seafood production (T. Pickerell, Shellfish Association of Great Britain, pers. comm.). 
Most of the 68000 extant species of Crustacea described to date are marine (Martin \& Davis 2001, 2006). While some groups are exclusively marine (e.g. cirripeds, euphausiids, stomapods) and occupy every available niche in the ocean, others are primarily marine, but have brackish, freshwater and semi-terrestrial/ terrestrial representatives (e.g. ostracods, copepods, isopods, amphipods, decapods). Subsequently, crustaceans occupy a range of aquatic habitats that experience differing degrees of environmental variability. Those occupying deep oceans and high latitudes come from relatively stable environments where physical factors show little variation over temporal and spatial scales. Other environments, such as the intertidal zone and estuaries, can experience wide and rapidly changing fluctuations in physical factors in response to diurnal changes in tidal height. In estuarine environments, seasonal changes in physical variables are affected by changes in the inputs of freshwater and nutrients. Consequently, crustaceans are unusual when compared with other marine taxa. This is because they show a wide variety of responses to salinity change, from those that can regulate against external changes to those that simply conform. Studies on crustaceans can therefore provide researchers with an ideal opportunity to examine the relationship between environmental variability and the capacity to tolerate ocean acidification, which has recently been debated in the literature (Fabry et al. 2008, Widdicombe \& Spicer 2008).

The purpose of the current review is to bring together, for the first time, all of the ocean acidification studies that have been carried out on crustaceans to date. The review will follow the development of the field from early physiological studies on the effects of hypercapnia to the effects of long-term exposure to more relevant $\mathrm{pCO}_{2}$ levels on individual performance and fitness. The physiological data will be used to investigate the presence of any emerging patterns or trends that may explain why certain groups of crustaceans are more vulnerable to ocean acidification than others. The subsequent ecological repercussions will be reviewed by summarising our current understanding of the following: the possible energetic implications of medium-term exposure to relevant $\mathrm{pCO}_{2}$ levels, the potential impacts on calcification rates and growth in crustaceans, as well as a summary of the latest observations on the effects of ocean acidification on development rates and larval survival. As such, the current review will use physiological and ecologically relevant responses to give an overall view on the biological effects of ocean acidification on crustaceans. This information will be used to identify areas for future research so that we can make a more informed assessment on the future prospects for marine crustaceans in a high $\mathrm{CO}_{2}$ world.

\section{PHYSIOLOGICAL RESPONSES TO OCEAN ACIDIFICATION}

The most immediate responses to ocean acidification in marine crustaceans are best described at the individual level by physiological adjustments to changes in seawater carbonate chemistry. As the majority of crustaceans are committed water-breathers, they are in close contact with their external environment via the gills or equivalent structures, which are specialised for respiratory gas and ion exchange (Taylor \& Taylor 1992). When carbonate chemistry of the seawater changes during ocean acidification, $\mathrm{CO}_{2}$ excretion across the gills is compromised, causing an increase in $\mathrm{CO}_{2}$ in the haemolymph (extracellular compartment). Subsequent changes in haemolymph $\mathrm{pH}$ are buffered to various extents by the mechanisms described in the following subsection. Such adjustments are important because they maintain the acid-base equilibria of the body fluids within the limits needed for protein function. This is particularly true for the intracellular compartment, where changes in $\mathrm{pH}$ are tightly controlled. A rise in intracellular $\left[\mathrm{H}^{+}\right]$can disrupt key biological processes such as metabolism, protein synthesis, iono-regulation and cell volume control (Gaillard \& Malan 1983, Wheatly \& Henry 1992, Whiteley 1999). Although pH disruptions can be tolerated in the haemolymph or extracellular compartment to some extent for short periods (hours), haemolymph $\mathrm{pH}$ regulation is important to maintain oxygen supply. Increasing $\left[\mathrm{H}^{+}\right]$will decrease the oxygen affinity of the respiratory pigment, reducing oxygen delivery to the tissues (Taylor \& Whiteley 1989, Whiteley \& Taylor 1992). Disruptions to extra- and intracellular acid-base balance can, therefore, have far-reaching consequences by compromising survival and adversely effecting ecologically relevant factors such as metabolism and growth.

\section{Short-term acute exposure to hypercapnia}

Most of what we currently understand about the physiological mechanisms involved in the compensation of acid-base imbalances comes from laboratorybased studies on decapod crustaceans (prawns, lobsters, portunid and xanthid crabs) exposed to acute elevations in $\mathrm{pCO}_{2}$ (hypercapnia). Although the $\mathrm{CO}_{2}$ levels investigated during short-term hypercapnia are much higher then the levels projected for future climate change scenarios, these studies are invaluable because they provide a mechanistic basis for understanding differences in the sensitivity of marine invertebrate taxa to ocean acidification (Fabry et al. 2008, Pörtner 2008, Widdicombe \& Spicer 2008, Melzner et al. 2009, Hale et al. 2011). Most importantly, the short- 
term exposure of crabs to either hypercapnia or external changes in salinity has demonstrated that acidbase balance is closely associated with iono-regulation because both homeostatic processes share the same mechanisms (Truchot 1975, 1981, 1992, Cameron 1978, Henry \& Cameron 1982, Cameron \& Iwama 1987, Whiteley 1999, Whiteley et al. 2001). Closer inspection of the mechanisms involved has revealed that $\mathrm{pH}$ adjustments in the haemolymph are buffered by haemolymph proteins (mainly haemocyanin) and bicarbonate ions. However, $\mathrm{pH}$ adjustments are dominated by electroneutral ion exchange across the gill epithelia, as the majority of buffer $\mathrm{HCO}_{3}{ }^{-}$comes from the external seawater $(93 \%)$ and the remainder $(7 \%)$ comes from internal stores (Cameron 1985). Moreover, crustacean species that are more tolerant to hypercapnia maintain a higher haemolymph $\mathrm{HCO}_{3}{ }^{-}$(Pörtner et al. 2004, Melzner et al. 2009), although $\mathrm{HCO}_{3}^{-}$levels do not generally exceed values $>50 \mathrm{mmol} \mathrm{l}^{-1}$ (Cameron \& Iwama 1987). During electroneutral ion exchange, inward $\mathrm{HCO}_{3}{ }^{-}$from the seawater is exchanged for $\mathrm{Cl}^{-}$after the catalysed hydration of $\mathrm{CO}_{2}$ by carbonic anhydrase, and outward $\mathrm{H}^{+}$is exchanged for $\mathrm{Na}^{+}$ (Taylor \& Taylor 1992, Wheatly \& Henry 1992, Whiteley 1999). These ion exchanges are driven by a basolateral $\mathrm{Na}^{+} / \mathrm{K}^{+}$-ATPase (Towle \& Kays 1986, Taylor \& Taylor 1992) and, possibly, an apical $\mathrm{H}^{+}$-ATPase (Onken \& Putzenlechner 1995, Freire et al. 2008). Consequently, environmental disruption of haemolymph acid-base status is more likely to be compensated in strong iono- and osmoregulators, where ion exchange mechanisms are well developed. This relationship could well explain why freshwater crustaceans, which are strong iono- and osmoregulators, can survive considerable acidification of their freshwater habits (Abrahamsson 1972, McMahon \& Stuart 1989, Felten et al. 2008, Weber \& Pirow 2009). Likewise, strong iono- and osmoregulators are likely to be less vulnerable to ocean acidification, because they possess the mechanisms that enable them to compensate for haemolymph acid-base disturbances, at least in the shorter term.

\section{Medium-term exposure to relevant $\mathrm{CO}_{2}$ levels}

Exposure to smaller increases in seawater $\mathrm{CO}_{2}$ (i.e. 0.10 to $0.20 \mathrm{kPa}$ ) over longer time intervals of weeks to months is more relevant to the potential changes that could occur as a result of ocean acidification. To date medium-term laboratory-based physiological studies in adult crustaceans have concentrated on alterations in compensatory capacities over time. The information available, however, is limited and can be traced back to a handful of studies that have either examined acid-base adjustments or calcification rates. Overall, it appears that medium-term exposure to $\mathrm{pCO}_{2}$ levels more representative of ocean acidification has the potential to adversely affect growth and reproduction by diverting energy towards the maintenance of effective compensatory responses.

Acid-base compensation and energetic repercussions

Only 3 studies have examined the ability of crustaceans to adjust internal acid-base imbalances during medium-term exposure to projected $\mathrm{pCO}_{2}$ levels. In the strong iono-regulating prawn species Palaemon elegans and $P$. serratus, complete compensation for a $\mathrm{pCO}_{2}$ of $0.30 \mathrm{kPa}$ was observed after $30 \mathrm{~d}$ of exposure (Dissanayake et al. 2010). However, ion homeostasis was maintained at the expense of acid-base balance. Two species of crabs, Necora puber and Cancer magister, which are relatively poor iono-regulators, were also able to compensate haemolymph acid-base disturbances within $24 \mathrm{~h}$ when exposed to $\mathrm{CO}_{2}$ at 0.10 to $0.20 \mathrm{kPa}$ (Pane \& Barry 2007, Spicer et al. 2007). Compensation in all 4 species was achieved by an elevation in haemolymph $\left[\mathrm{HCO}_{3}{ }^{-}\right]$. Continued exposure to the same $\mathrm{pCO}_{2}$ level in $N$. puber had a detrimental effect, as bicarbonate buffering started to fail after $16 \mathrm{~d}$ when $\left[\mathrm{HCO}_{3}{ }^{-}\right]$reached $27 \mathrm{mmol} \mathrm{l}^{-1}$ (Spicer et al. 2007). However, haemolymph $\left[\mathrm{HCO}_{3}^{-}\right]$was found to be much lower after $30 \mathrm{~d}$ at the same $\mathrm{pCO}_{2}$ in a separate study (Small et al. 2010). Exposure to an even higher $\mathrm{pCO}_{2}$ level of $2 \mathrm{kPa}(\mathrm{pH}$ of 6.05 ) limited survival to between 4 and $5 \mathrm{~d}$, because haemolymph $\mathrm{pH}$ fell despite a huge increase in haemolymph buffer base up to $55 \mathrm{mmol} \mathrm{l}^{-1}$ (Spicer et al. 2007). This bicarbonate value is similar to the maximum value obtained by Cameron \& Iwama (1987) for the blue crab Callinectes sapidus during hypercapnia. Both observations support the existence of a threshold $\left[\mathrm{HCO}_{3}^{-}\right]$in the haemolymph of approximately $50 \mathrm{mmol} \mathrm{l}^{-1}$. The inability to increase $\left[\mathrm{HCO}_{3}{ }^{-}\right]$ beyond this level is thought to be a compromise between acid-base balance and iono-regulation, although it is also possible that the medium-term adjustments are metabolically expensive as suggested by Pörtner et al. (2004) for other invertebrate species.

Acid-base adjustments made by crustaceans are likely to be metabolically expensive over weeks to months, due to the dependence on $\mathrm{HCO}_{3}{ }^{-}$uptake from the seawater via electroneutral ion exchange. Electroneutral exchange of $\mathrm{HCO}_{3}{ }^{-}$for $\mathrm{Cl}^{-}$and $\mathrm{H}^{+}$for $\mathrm{Na}^{+}$is, in turn, dependent on the presence of ion gradients across transport epithelia that are maintained by active ion-transporting pumps, $\mathrm{Na}^{+} / \mathrm{K}^{+}$- and $\mathrm{H}^{+}$-ATPases (Cameron \& Iwama 1987, Pörtner et al. 2004, Santos et al. 2007). The actual costs associated with active ion 
transport are unclear, but estimates of $\mathrm{Na}^{+} / \mathrm{K}^{+}$-ATPase activity range from 2.8 to $40 \%$ of total energy expenditure, indicating a considerable cost to the individual (Pannevis \& Houlihan 1992, Leong \& Manahan 1997). If the costs associated with the acid-base balance are indeed significant, then crustaceans that are good compensators could be adversely affected during ocean acidification. Either the costs will be limiting and restrict homeostatic processes or energy will be diverted away from other energy-demanding processes. In both situations, individual performance will be affected. Even though the energetic consequences of ocean acidification are unknown, some indication of the possible effects on performance can be obtained from experiments in which crustaceans are acclimated to various salinities. For instance, it is well known that the maintenance of ion gradients between the extracellular fluid and the external medium is energetically costly, especially during hypo- and hyper-osmoregulation (Gilles 1983, Moreira et al. 1983, McNamara \& Moreira 1987, Péqueux 1995, Freire et al. 2008). The increase in energetic costs associated with iono-regulation has recently been used to explain differences in protein synthesis rates in the tropical prawn Macrobrachium rosenbergii (Intanai et al. 2009). In M. rosenbergii whole animal fractional rates of protein synthesis were highest at an iso-osmotic salinity of 14 psu, when the prawns were expending the minimal amount of energy on iono- and osmoregulation (Wang et al. 2004, Intanai et al. 2009). As protein synthesis rates are a major determinant of growth, these observations suggest that growth was compromised during hypoand hyper-osmoregulation. Whether ocean acidification would have a similar effect on protein synthesis rates is not yet known.

Given that the energetic costs of acid-base regulation could be fairly substantial, it is also possible that the associated costs themselves could decrease during ocean acidification to reduce ATP demand. Such a response has been observed in the musculature of the intertidal polychaete Sipunculus nudus during hypercapnia (Pörtner et al. 2000). In this species, intracellular $\mathrm{pH}$ is protected during an extracellular acidosis by an increase in the importance of $\mathrm{Na}^{+}$-dependent $\mathrm{Cl}^{-} / \mathrm{HCO}_{3}^{-}$exchange for $\mathrm{H}^{+}$transport over $\mathrm{Na}^{+} / \mathrm{H}^{+}$, $\mathrm{Na}^{+} / \mathrm{K}^{+}$-ATPase, and possibly $\mathrm{H}^{+}$-ATPase activity. The benefit here is the shift in ion-transporting mechanisms from those with higher to lower ATP demands. An extracellular acidosis in $S$. nudus was accompanied by a decrease in metabolic rate, suggesting that a decrease in the energetic demands of acid-base regulation has an effective energy-saving role (Pörtner et al. 1998, 2000). Whether this strategy exists in crustaceans exposed to more moderate increases in $\mathrm{pCO}_{2}$ is not known.

\section{Calcification rates}

Currently it is relatively unclear whether the net calcification rate (balance between rates of calcification and dissolution) of the chitinous-mineralised crustacean exoskeleton will be adversely affected by ocean acidification. Calcification processes in crustaceans are likely to be less vulnerable to ocean acidification than those present in echinoderms or molluscs, because exoskeletal $\mathrm{CaCO}_{3}$ is mostly in the more stable form of calcite rather than the more soluble aragonite (Boßelmann et al. 2007, Neues et al. 2007). In addition, calcification processes are well removed from external changes in seawater carbonate chemistry and are known to depend on $\mathrm{HCO}_{3}{ }^{-}$rather than on $\mathrm{CO}_{3}{ }^{2-}$ (Cameron 1985). The crustacean exoskeleton also contains amorphous calcium carbonate, which is highly soluble and acts as a transient source of $\mathrm{Ca}^{2+}$ (Boßelmann et al. 2007, Neues et al. 2007). It is tempting to speculate that amorphous $\mathrm{CaCO}_{3}$ may also act as a source of $\mathrm{HCO}_{3}{ }^{-}$for acid-base homeostasis. Interestingly, the proportion of amorphous calcium salts in the exoskeleton varies between species and depends on lifestyle (Neues et al. 2007). It may therefore influence compensatory capacities by providing a labile source of $\mathrm{HCO}_{3}{ }^{-}$. Currently, it is not known how these various forms of $\mathrm{CaCO}_{3}$ are affected by ocean acidification. However, the formation of $\mathrm{CaCO}_{3}$ in the crustacean exoskeleton is thought to depend on the maintenance of an alkaline $\mathrm{pH}$ in the exoskeletal compartment, which is reported to be $0.3 \mathrm{pH}$ units higher than that in the haemolymph (Wood \& Cameron 1985).

Despite the lack of information on calcification processes in crustaceans, ocean acidification has the potential to influence calcification rates in 2 ways. First, ocean acidification could influence precipitation of $\mathrm{CaCO}_{3}$ in the exoskeleton by reducing the alkaline $\mathrm{pH}$ in the exoskeletal compartment (Wood \& Cameron 1985). Second, ocean acidification could interfere with post-moult calcification of the new exoskeleton, which is dependent on a large uptake of $\mathrm{Ca}^{2+}$ and $\mathrm{HCO}_{3}{ }^{-}$ across the gills from the surrounding seawater (Neufield \& Cameron 1992, Wheatly 1997). The influx of $\mathrm{Ca}^{2+}$ and $\mathrm{HCO}_{3}{ }^{-}$is particularly sensitive to an increase in external $\left[\mathrm{H}^{+}\right]$as it reduces branchial $\mathrm{HCO}_{3}{ }^{-}$uptake (Cameron 1985, Cameron \& Wood 1985). This suggests that the reductions in seawater $\mathrm{pH}$ associated with ocean acidification could potentially interfere with post-moult calcification. A similar response has been observed in the blue crab Callinectes sapidus during hypercapnia. In this species, post-moult calcification, which normally takes $14 \mathrm{~d}$, took twice as long, as the $\mathrm{HCO}_{3}{ }^{-}$necessary for calcification was obtained from metabolic $\mathrm{CO}_{2}$ (Cameron 1985). Any delay in the postmoult calcification process could be fatal, as crus- 
taceans are particularly vulnerable to predation during this period. Their exoskeletons are soft, and the newly moulted crustaceans are unable to move or defend themselves. As a consequence, ocean acidification has the potential to increase mortality rates indirectly by delaying the calcification process during moulting.

Despite the potential for adverse effects on calcification rates, medium-term exposure to moderate elevations in seawater $\mathrm{CO}_{2}$ indicates that the calcified structures in crustaceans (exoskeleton and the barnacle shell wall plates) are well protected from ocean acidification. In all crustacean species studied to date, calcification rates either remain the same or increase after a period of $\mathrm{CO}_{2}$ exposure (Wickins 1984, Findlay et al. 2009, McDonald et al. 2009, Ries et al. 2009). An increase in calcium content was first observed in the exoskeleton of Penaeus monodon after $36 \mathrm{~d}$ of exposure to a decrease in seawater $\mathrm{pH}$ of 7.9 to $6.4 \mathrm{pH}$ units (Wickins 1984). A similar response was observed in the blue crab Callinectes sapidus, the king prawn Penaeus plebejus and the lobster Homarus americanus (Ries et al. 2009). All 3 species were exposed to seawater equilibrated with $\mathrm{pCO}_{2}$ levels that were 2, 3 and 10 times higher than pre-industrial levels $(0.06 \pm 0.01,0.09 \pm$ 0.01 and $0.29 \pm 0.05 \mathrm{kPa}$, respectively) for $60 \mathrm{~d}$, which is nearly twice the exposure period experienced by P. monodon in the earlier study by Wickins (1984). Such a response may reflect the ability to effectively maintain elevated $\mathrm{pH}$ levels at the site of calcification. It may also demonstrate that the outer organic layer, or epicuticle, acts as an effective barrier between the mineralised exoskeleton and the seawater (Ries et al. 2009). In contrast, long-term exposure to a $\mathrm{pCO}_{2}$ of $0.01 \mathrm{kPa}$ for $30 \mathrm{wk}$ resulted in morphological damage in the marine shrimp P. pacificus, due to shortening of the second antennae (Kurihara et al. 2008). The authors attributed this damage to the dissolution of $\mathrm{CaCO}_{3}$ stores by the ensuing disruptions to acid-base homeostasis, which are more likely to occur in the long term.

Recent studies on 2 species of intertidal barnacles have revealed differences in net calcification rates during elevated $\mathrm{pCO}_{2}$. In the tropical barnacle Amphibalanus amphitrite, an increase in the calcification rate was implied by the observed increase in basal shell diameter after $11 \mathrm{wk}$ at $\mathrm{pH}$ 7.4, which required greater force to cause shell breakage (McDonald et al. 2009). Compensatory responses, however, were localised, as the central wall plates succumbed to dissolution at $\mathrm{pH} 7.4$ and were weaker than individuals held at $\mathrm{pH}$ 8.1. This observation suggested that individuals held at $\mathrm{pH} 7.4$ would be more vulnerable to predation. In contrast, the maintenance of mineral content in the shells of the cold-temperate/boreal barnacle species Semibalanus balanoides after $20 \mathrm{~d}$ at pH 7.3 indicated an ability to compensate for shell dissolution in sea- water saturated with aragonite and calcite, but an inability to enhance calcification rates (Findlay et al. $2010 b)$. Given that the growth rates of $S$. balanoides were slower at $\mathrm{pH} 7.3$ than at $\mathrm{pH}$ 8.1, Findlay et al. (2010b) concluded that calcification of the shell under acidifying conditions was energetically demanding, resulting in the reallocation of resources, which compromised individual fitness. Clearly, crustaceans show some ability to compensate net calcification rates for medium-term exposure at relevant $\mathrm{pCO}_{2}$. However, a few detrimental effects were observed due to reductions in the strength of calcified protective plates and reductions in growth rates.

\section{EMERGING PATTERNS OF VULNERABILITY: THE PHYSIOLOGICAL EVIDENCE}

Some generalisations about the crustacean groups most likely to be affected by ocean acidification can be made by combining physiological responses from earlier studies on hypercapnia with those from recent experiments on long-term exposures to more moderate levels of $\mathrm{pCO}_{2}$ (Pane \& Barry 2007, Spicer et al. 2007, Widdicombe \& Spicer 2008). To date, it appears that vulnerability to ocean acidification may be related to differences in lifestyle and to differences in the ability to compensate for environmental change. As stated previously, it is predicted that strong iono- and osmoregulating species are likely to be the most tolerant to ocean acidification, simply because they have the compensatory mechanisms to respond to acid-base disruptions. These species tend to inhabit shallow coastal environments under freshwater influence, where they experience natural variations in seawater $\mathrm{pCO}_{2}, \mathrm{pO}_{2}$, salinity and temperature. For instance, when left behind in rock pools during the night, crabs can experience increased $\mathrm{pCO}_{2}$ and decreased $\mathrm{pH}$ levels and $\mathrm{pO}_{2}$ in the seawater (Truchot \& Duhamel-Jouve 1980, Morris \& Taylor 1983). Marine crustaceans can also be exposed to increased $\mathrm{pCO}_{2}$ in deep-sea vent systems and in the surface waters of the open ocean where they also experience vertical gradients in $\mathrm{pH}$ and $\mathrm{pO}_{2}$ (Fabry et al. 2008). Early physiological studies have demonstrated that the ability to compensate acid-base disturbances in the face of environmental change is highly variable among species. This is true among those species that have a subtidal distribution and experience stable conditions in their natural environment. For instance, aerial exposure and subsequent elevation of haemolymph $\mathrm{CO}_{2}$ is fully compensated by the European lobster Homarus gammarus, is partially compensated by the edible crab Cancer pagurus and remains uncompensated in the swimming crab Necora puber and the spider crab Maja squinado (Taylor \& 
Whiteley 1989, Whiteley 1999). Moreover, physiological studies have shown that some species of intertidal crabs do not compensate for the effects of aerial exposure when exposed at low tide (Burnett \& McMahon 1987). Instead they undergo metabolic depression and wait until the tide returns. Despite these differences in compensatory capacities, $N$. puber and $C$. magister are able to survive exposure to $\mathrm{pCO}_{2}$ levels more relevant to ocean acidification, at least in the medium-term, i.e. up to 60 d (Pane \& Barry 2007, Spicer et al. 2007, Small et al. 2010). Consequently, it remains unclear whether the ability of crustaceans to compensate for highly variable environments increases their tolerance to ocean acidification. However, this may have more to do with the limited data set collected to date and less to do with existing patterns of vulnerability. Clearly, there is a need to investigate the physiological responses in crustacean species from a broader range of marine habitats during exposure to relevant ocean acidification conditions for longer periods of time.

The ability to compensate for the effects of ocean acidification can also vary with lifestyle. Decapod crustaceans with high rates of activity have a greater capacity for passive compensation of haemolymph acidbase disturbances (i.e. buffering by non-bicarbonate buffers) than slow-moving, relatively inactive species due to species-related differences in respiratory variables. Relatively fast-moving species, such as the swimming crab Necora puber, have higher circulating levels of haemocyanin than slow-moving, relatively inactive crabs, such as Maja squinado (Watt et al. 1999). Higher haemocyanin levels lead to higher oxygencarrying and non-bicarbonate-buffering capacities, in keeping with the higher aerobic requirements and higher rates of metabolic $\mathrm{CO}_{2}$ production. The lower haemocyanin levels characteristic of slow-moving species are associated with relatively low rates of oxygen uptake and relatively high levels of circulating lactate levels, showing some reliance on anaerobic metabolism (Watt et al. 1999). Similar characteristics may contribute to the inability of the deep-sea tanner crab Chionoecetes tanneri to buffer an accumulating haemolymph acidosis when exposed to short-term hypercapnia $\left(1 \% \mathrm{CO}_{2}, \sim 1.28 \mathrm{kPa}\right.$, for $\left.24 \mathrm{~h}\right)$ (Pane \& Barry 2007). For example, haemolymph protein levels were significantly lower in C. tanneri than those determined in a shallow-water species, Cancer magister, under the same conditions. The reduction in buffering capacity in C. tanneri was compounded by a failure to raise $\mathrm{HCO}_{3}{ }^{-}$ levels beyond $3 \mathrm{mmol} \mathrm{l}^{-1}$ (Pane \& Barry 2007). The lack of compensatory ability could be explained by the low temperatures at which the measurements were taken $\left(3^{\circ} \mathrm{C}\right)$ or by the fact that deep-sea crabs have low metabolic rates, in keeping with their habitation of a stable, harsh and resource-limited environment.
By inference, these observations suggest that other species living in similarly low-energy environments will be susceptible to ocean acidification. This is particularly pertinent at polar latitudes, where marine invertebrates are stenothermal, have poor thermal tolerances and are characterised by relatively low metabolic rates (Peck 2002, Pörtner et al. 2007). Acid-base characteristics have only been determined in 1 species of polar marine crustaceans, the giant Antarctic isopod Glyptonotus antarcticus. This species has relatively low circulating levels of protein, resulting in low haemocyanin oxygen-carrying and protein-buffering capacities (Whiteley et al. 1997). The latter is 2.5- to 7.5-fold lower than the range of values estimated in other aquatic crustaceans (Taylor \& Taylor 1992). Not only is the lower buffering capacity a problem in terms of compensating for the effects of ocean acidification, the oxygen affinity of $G$. antarcticus haemocyanin is highly sensitive to a reduction in $\mathrm{pH}$ (Jokumsen et al. 1981). Both characteristics decrease the involvement of the respiratory pigment in the transport of oxygen from the gills to the tissues. It appears that $G$. antarcticus, just like the deep-sea crab Chionoecetes tanneri, will be unable to compensate for the effects of ocean acidification. As a result, both species will be more vulnerable to the associated changes in seawater chemistry.

\section{POTENTIAL ECOLOGICAL EFFECTS OF OCEAN ACIDIFICATION}

Very little information is available on the potential impacts of ocean acidification on the ecology of crustaceans. There is some evidence to show that ocean acidification may affect crustacean species at the population level by influencing the growth or reproductive performance of adults. In addition, there is a growing interest in the potential effects of ocean acidification on early life-cycle stages in benthic and pelagic crustacean species. Collectively, it appears that sensitivities to ocean acidification vary among species and with ontogeny. However, the lack of data makes it difficult to observe any emerging trends, and it is impossible to discuss the available information without resorting to individual studies.

\section{Effects of ocean acidification on growth rate}

The only evidence to date of the effects of elevated $\mathrm{pCO}_{2} /$ reduced $\mathrm{pH}$ on growth rates in adult crustaceans comes from 1 species of marine shrimp and 2 species of penaeid prawns (Wickins 1984, Kurihara et al. 2008). Growth rates in all 3 species were affected by elevated $\mathrm{CO}_{2}$, but the marine shrimp Palaemon pacificus was 
more sensitive than Penaeus occidentalis or P. monodon (Table 1). Not surprisingly, $\mathrm{CO}_{2}$ had more of an effect when levels were increased and seawater $\mathrm{pH}$ was reduced to $7.6 \mathrm{pH}$ units or lower. For example, when adult $P$. pacificus were held at a $\mathrm{pCO}_{2}$ of $0.10 \mathrm{kPa}(\mathrm{pH}=7.89 \pm 0.05)$ there was no change in growth rate for $30 \mathrm{wk}$ and then only in females (Kurihara et al. 2008). At the higher $\mathrm{pCO}_{2}$ level of $0.20 \mathrm{kPa}$ $(\mathrm{pH}=7.64 \pm 0.09)$, both growth rate and moult frequency decreased after $7 \mathrm{wk}$, and no animals survived beyond 15 wk. In penaeids, the growth rate declined when seawater $\mathrm{pH}$ fell below 7.4 due to a decrease in moulting frequency and an increase in intermoult period from 5 to 6-9 d (Wickins 1984).

\section{Effects of ocean acidification on reproduction and development}

Our understanding of the reproductive effects of ocean acidification in crustaceans is restricted to a small number of observations on egg production, and rates of embryonic and larval development (Table 1). Changes in egg production were observed in Palaemon pacificus held at a $\mathrm{pCO}_{2}$ of $0.10 \mathrm{kPa}$ (Kurihara et al. 2008). Higher levels of $\mathrm{pCO}_{2}(0.20 \mathrm{kPa})$, however, had no effect on egg production in the copepods Acartia tsuensis and A. steueri after $27 \mathrm{~d}$ of exposure (Kurihara et al. 2004a,b, Kurihara \& Ishimatsu 2008) or in the barnacle Amphibalanus amphitrite held at $\mathrm{pH} 7.4$ (McDonald et al. 2009). The influence of elevated $\mathrm{CO}_{2}$ on embryonic development has only been investigated in 1 barnacle species, Semibalanus balanoides. In this intertidal species, a $\mathrm{pCO}_{2}$ of $0.09 \mathrm{kPa}$ reduced rates of embryonic development in isolated egg masses and delayed time to hatching by $19 \mathrm{~d}$ (Findlay et al. 2009).

In contrast, there is little evidence to show that ocean acidification is detrimental to larval and juvenile stages (Table 1). Currently, data on larval development under relevant levels of $\mathrm{pCO}_{2}$ are available for 4 crustacean species: the copepod Acartia tsuensis (Kurihara \& Ishimatsu 2008), the barnacle Amphibalanus amphitrite (McDonald et al. 2009), the lobster Homarus gammarus (Arnold et al. 2009) and the spider crab Hyas

Table 1. Effects of elevated seawater $\mathrm{CO}_{2}$ on indices of growth and reproductive capacity in a variety of crustacean species. pCO tial pressure of $\mathrm{CO}_{2}$ calculated from values published as ppm (mole fraction) assuming a barometric pressure of $101.35 \mathrm{kPa}$. Dashes represent absence of available data

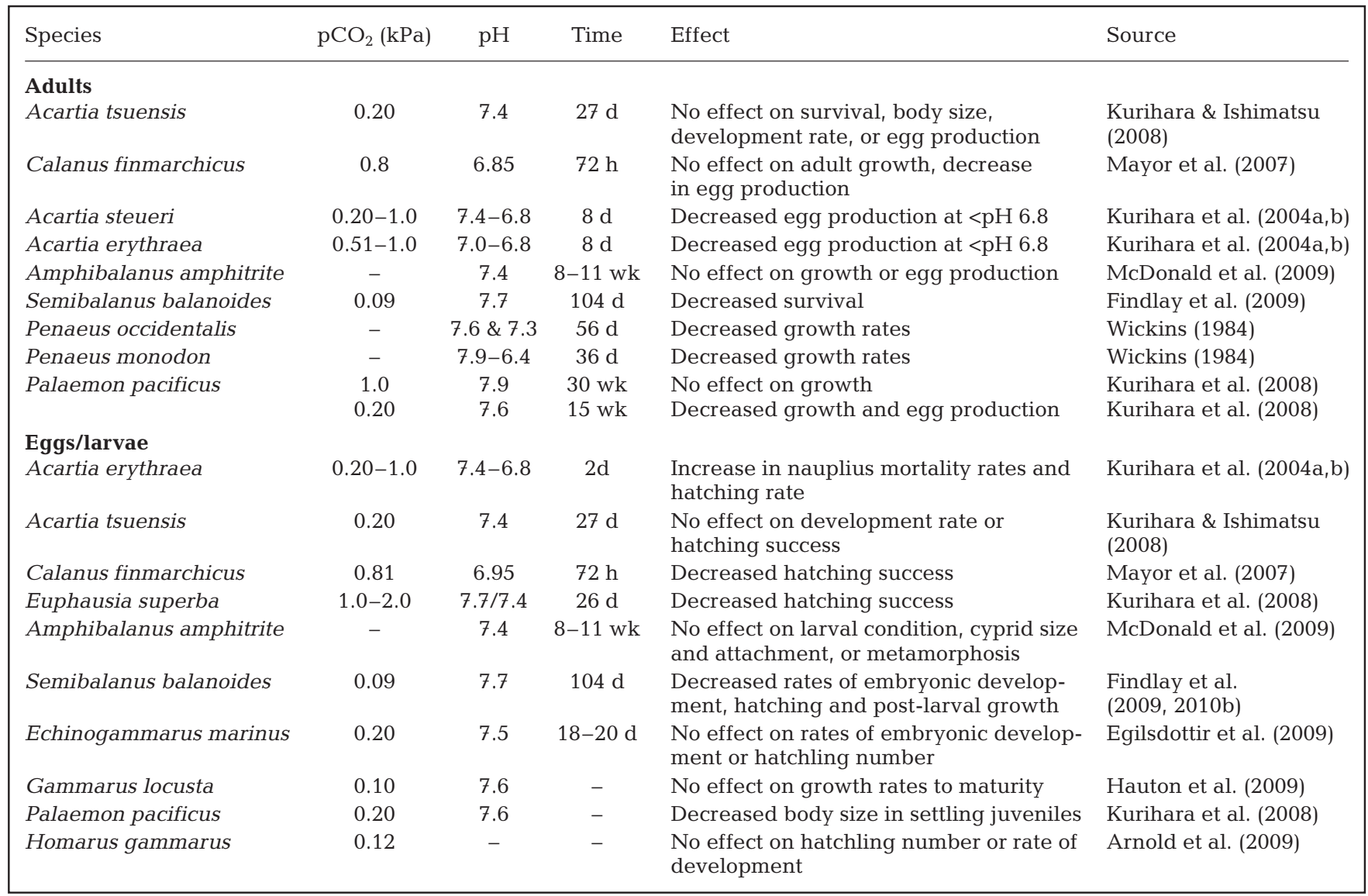


araneus (Walther et al. 2010). In all 4 species, elevation in $\mathrm{pCO}_{2}$ to $<0.02 \mathrm{kPa}$ had no effect on rates of larval survival or development (Table 1). In addition, elevated $\mathrm{pCO}_{2}$ had no effect on larval condition and cyprid size, attachment, or metamorphosis in A. amphitrite (McDonald et al. 2009). In H. gammarus, this may be due to the fact that the exoskeletons of planktonic decapod larvae (zoeae) are unmineralised, while those of megalopae and benthic juveniles are only partially calcified (Anger 2001). This is likely to reduce the potential negative effects of ocean acidification on calcification rates during larval moults. Hatching success in the copepods Acartia erythraea and Calanus finmarchicus was negatively affected, but at $\mathrm{pCO}_{2}$ levels of 0.50 to $0.80 \mathrm{kPa}$, which far exceed the values predicted for the year 2300 (Kurihara et al. 2004a,b, Mayor et al. 2007). In addition, the growth rates of early life stages of Semibalanus balanoides from the metamorphosing cyprids to early juveniles were significantly reduced by a decrease in seawater $\mathrm{pH}$ from 8.1 to $7.3(\sim 0.04$ to $0.30 \mathrm{kPa}$ ) (Findlay et al. 2010b). A similar drop in $\mathrm{pH}$ (8.2 to 7.4 ), however, had no effect on juvenile to adult growth rates in the tropical barnacle A. amphitrite (McDonald et al. 2009). In addition, reductions in $\mathrm{pH}$ down to $7.8(0.06 \mathrm{kPa})$ and $7.6(0.10 \mathrm{kPa})$ had no effect on the growth rates of juveniles to adolescence or to sexual maturity in the amphipod Gammarus locusta (Hauton et al. 2009).

\section{COMBINED EFFECTS OF OCEAN ACIDIFICATION AND OTHER ENVIRONMENTAL VARIABLES}

Apart from some early work, the interactive effects of multiple stressors on the survival of marine crustaceans has been poorly studied, despite the fact that ocean acidification is occurring simultaneously with changes in temperature, salinity and oxygen. Early physiological studies on the effects of diurnal changes in temperature, $\mathrm{pCO}_{2}$ and $\mathrm{pO}_{2}$ that occur naturally in rock pools demonstrated that acid-base changes in the haemolymph of the shore crab Carcinus maenas were less than those induced by exposure to a single factor (Truchot 1986). The combined effects of hypoxia and hypercapnia at night and the reverse situation during the day had opposing effects on acid-base balance and acted to minimise physiological disturbances. Moreover, the environmental changes happened so rapidly that $\mathrm{HCO}_{3}{ }^{-}$did not have time to accumulate in the haemolymph. Instead, an increase in haemolymph $\mathrm{pH}$ was brought about by hypoxia-induced hyperventilation. In contrast, the simultaneous exposure of decapod crustaceans to hypoxia and hypercapnia in the laboratory resulted in the accumulation of haemolymph $\mathrm{HCO}_{3}^{-}$, which fully compensated the haemo- lymph acidosis (Truchot 1984, Burnett 1997). In Callinectes sapidus, for example, haemolymph $\mathrm{pH}$ remained unchanged during hypoxia at a $\mathrm{pCO}_{2}$ of $0.35 \mathrm{kPa}$, and even increased at a $\mathrm{pCO}_{2}$ of $0.49 \mathrm{kPa}$ (Burnett 1997). The increase in haemolymph $\mathrm{pH}$ or alkalosis was beneficial to the crabs, especially during hypoxia, as it served to increase haemocyanin oxygen affinity and hence oxygen loading at the gills (Burnett 1997). A small increase in L-lactate levels in the haemolymph during hypoxia would have had the same effect (Truchot 1980, Burnett 1997). In contrast to C. sapidus, the deep-sea crab Chionoecetes tanneri, which has a relatively poor capacity for acid-base compensation, was unable to buffer the haemolymph acidosis induced by exposure to both hypoxia and hypercapnia (Pane \& Barry 2007).

Of the few studies that have been carried out to date, most have focused on the combined effects of ocean acidification and temperature. Attention has either been given to the physiological responses of adults or to the survival rates of larvae. In adult crustaceans, the physiological consequences of ocean acidification and temperature have been restricted to 2 species of subtidal crabs, Cancer pagurus and Hyas araneus (Metzger et al. 2007, Walther et al. 2009), and to a species of nektonic shallow-water prawn, Metapenaeus joyneri (Dissanayake \& Ishimatsu 2011). In C. pagurus, exposure to $1 \% \mathrm{CO}_{2}(\sim 1.0 \mathrm{kPa})$ and either a progressive decrease or increase in temperature reduced upper thermal limits and increased mortality rates (Metzger et al. 2007). A similar response was observed in the spider crab $H$. araneus, when exposed to more relevant $\mathrm{pCO}_{2}$ levels of 0.07 and $0.30 \mathrm{kPa}$ (Walther et al. 2009). An elevation in $\mathrm{pCO}_{2}$ in $H$. araneus not only lowered the upper thermal tolerance limit, it also increased the heart rate and reduced haemolymph $\mathrm{pO}_{2}$ levels when temperatures rose above $10^{\circ} \mathrm{C}$. Collectively, these data suggest that thermal tolerances are reduced in crabs under high $\mathrm{CO}_{2}$ conditions, due to a limitation in oxygen supply as described in teleost fishes by Pörtner \& Farrell (2008). Elevated $\mathrm{pCO}_{2}$ and temperature can also affect swimming performance, as exposure of $M$. joyneri to a $\mathrm{pCO}_{2}$ of $1.0 \mathrm{kPa}$ at 3 acclimation temperatures $\left(10,15\right.$ and $\left.25^{\circ} \mathrm{C}\right)$ for $10 \mathrm{~d}$ significantly reduced critical swimming speeds (Dissanayake \& Ishimatsu 2011). However, elevated $\mathrm{pCO}_{2}$ had more of an effect on swimming performance than temperature, even though acclimation to the highest temperature $\left(25^{\circ} \mathrm{C}\right)$ decreased aerobic scope (difference between standard and active metabolic rates). The authors attributed this observation to the fact that the prawns were held at temperatures outside their normal thermal optima (Dissanayake \& Ishimatsu 2011). As a consequence, oxygen supply was restricted and aerobic performance was reduced. Given that reductions in 
thermal tolerance windows have been linked to reductions in growth performance and reproductive activity, as well as reductions in biogeographical ranges and shifts in community composition, the combined effects of ocean acidification and temperature could have wide-ranging ecological implications (Pörtner 2002, 2010, Somero 2002, Pörtner \& Farrell 2008).

Ecological studies have concentrated on the effects of elevated $\mathrm{pCO}_{2}$ and temperature on the growth and survival of post-larvae from 2 species of barnacles (Findlay et al. 2010a,b) and from the spider crab Hyas araneus (Walther et al. 2010). Even though both barnacle species were collected from similar intertidal habits on the southwestern coast of England, differences in growth and shell development were observed between the cold-water species Semibalanus balanoides and the warm-water species Elminius modestus (Findlay et al. 2010a). Exposure to $\mathrm{pCO}_{2}$ levels of 0.04 and $0.10 \mathrm{kPa}$ at 2 temperatures $\left(14\right.$ and $\left.18^{\circ} \mathrm{C}\right)$ had no effect on post-larval growth rates in $S$. balanoides, but the higher $\mathrm{pCO}_{2}$ and temperature treatment significantly reduced growth rates in E. modestus. In contrast, the shell calcium content in $S$. balanoides was reduced by $\mathrm{CO}_{2}$ and by temperature, but neither factor had any effect on the calcification rates in E. modestus. In summary, it appears that $S$. balanoides post-larvae are able to maintain growth, but at the expense of shell calcification. On the other hand, E. modestus post-larvae are able to maintain the integrity of their calcified shells, but at the expense of growth. The ability to maintain mineralised shell plates during elevated $\mathrm{pCO}_{2}$ and temperature exposure was attributed to differences in thermal tolerance brought about by sampling populations from different parts of their geographic distribution (Findlay et al. 2010a). Interestingly, a sub-arctic population of the cold-water species $S$. balanoides was observed to be more sensitive to $\mathrm{CO}_{2}$ than the population in southwestern England, at the southern limit of its distribution range (Findlay et al. 2010a,b). Growth and development of post-larval $S$. balanoides from Kongsfjorden, Svalbard, at $79^{\circ} \mathrm{N}$, was negatively impacted by elevated $\mathrm{CO}_{2}$, but surprisingly an increase in temperature of $+4^{\circ} \mathrm{C}$ had no effect (Findlay et al. 2010 b). In contrast to the southern population, the northern population of $S$. balanoides also managed to maintain net calcification of their shells during elevated $\mathrm{CO}_{2}$, suggesting that resources were reallocated from 1 energy-demanding process to another as discussed in greater detail by Findlay et al. (2010b). Comparisons between populations of $H$. araneus from similar latitudes (temperate and sub-arctic) revealed that development time was slower in the northern compared with the southern population under present day $\mathrm{pCO}_{2}$ conditions $(0.04 \mathrm{kPa})$ (Walther et al. 2010). An elevation in $\mathrm{pCO}_{2}$ to $0.30 \mathrm{kPa}$ delayed rates of develop- ment and reduced growth rates and overall fitness of larvae from both populations. An increase in $\mathrm{pCO}_{2}$ to $0.07 \mathrm{kPa}$, however, had no effect. The megalopa emerged as the most vulnerable stage of development in $H$. araneus, as it was the most sensitive to temperature in the north and the most sensitive to $\mathrm{CO}_{2}$ levels in the south. The authors attributed the increase in sensitivity in the megalopa to reductions in thermal tolerance (Walther et al. 2010). They also predicted that both ocean acidification and global warming would affect the recruitment of the benthic juvenile stages in this species. A decrease in the abundance of $H$. araneus has already been observed in the North Sea around Helgoland, where temperatures have increased by $1.1^{\circ} \mathrm{C}$ over the last $40 \mathrm{yr}$ (Walther et al. 2010).

Finally, the specific effects of elevated $\mathrm{pCO}_{2}$ and temperature on marine community diversity and structure have recently been addressed by using artificial substrate units planted on the shore at extreme low tide (Hale et al. 2011). After the establishment of marine invertebrate communities, the artificial substrate units were removed and exposed to 8 different treatments (4 pH levels at 2 different temperatures). After $60 \mathrm{~d}$ of exposure, the combination of low $\mathrm{pH}(7.3$ and 6.7$)$ and elevated temperature $\left(16^{\circ} \mathrm{C}\right)$ significantly changed community structure and lowered diversity. However, at the higher $\mathrm{pH}$ levels (8.0 and 7.7) and elevated temperature, species abundance and diversity increased. Relevant to the present review was the fact that while molluscs and echinoderms were the most affected, and annelids the least, crustaceans showed an intermediate response. More specifically, gammaridean amphipods showed a marked decrease in abundance at low $\mathrm{pH}$ and elevated temperatures, but increased in abundance along with an isopod species at pH 7.7 and 7.3. Furthermore, the loss of the skeleton shrimp Caprella acanthifera from the higher temperature treatments contributed to changes in species richness. Overall this community-based mesocosm study revealed that the ecological impacts of the 2 environmental variables were greater than either factor in isolation. In addition, the study concluded that the changes in community structure were due to speciesspecific differences in tolerances (Hale et al. 2011). However, the authors stipulated that ecosystem-level responses to ocean acidification and global warming could not simply be explained by a reduction in individual performances. They also attributed the observed responses in species diversity to changes in community interactions, their argument being that the loss of the more vulnerable species provided opportunities for more tolerant species.

The dependence of community-led changes in marine ecosystems during ocean acidification on speciesspecific physiological tolerances has parallels to the 
selective survivorship associated with the PermoTriassic mass extinction, which occurred around 250 million yr ago (Pörtner et al. 2005, Knoll et al. 2007). This extinction event resulted in the loss of up to $54 \%$ of late Permian marine families, $68 \%$ of the genera and $92 \%$ of the species, resulting in a major re-organisation of the marine ecosystem. It has been argued that these ancient extinctions can be explained in terms of the physiological responses of marine invertebrates to the combined effects of environmental hypoxia, hypercapnia, sulphide toxicity and rising temperatures that prevailed at the time (Pörtner et al. 2005, Knoll et al. 2007). Moreover, the ability to compensate for hypercapnia is thought to be a key to survival. Interestingly, those groups that were more vulnerable to hypercapnia experienced significantly higher rates of extinction, although survival rates were also related to the presence or absence of a calcified exoskeleton and its relative proportion to soft tissues (Knoll et al. 2007). Arthropods were described by Knoll et al. (2007) as possessing a calcium carbonate skeleton of moderate mass with respect to supportive tissue and body fluids that were relatively well buffered. Although not the most vulnerable grouping, this group lost around $54 \%$ of its genera during the end-Permian mass extinction.

In summary, it appears that, in adult crustaceans, an increase in $\mathrm{pCO}_{2}$ to $1.0 \mathrm{kPa}$ during an increase in temperature causes physiological disruption and has a synergistic effect on an individual's performance. An increase in mortality rates was also observed in the subtidal crab Cancer pagurus (Metzger et al. 2007) and in the shallow-water prawn Metapenaeus joyneri during moulting (Dissanayake \& Ishimatsu 2011). However, the sensitivity to multiple stressors varies among species, with differential effects on individual fitness and survival leading to changes in community structure and interactions in an intertidal marine community (Hale et al. 2011). Such differences could also explain selective survival during the end-Permian mass extinction when there was a diversity collapse in the marine environment (Knoll et al. 2007). Overall the combination of $\mathrm{CO}_{2}$ and temperature levels relevant to ocean acidification and global warming have little effect on the performance of post-larvae, at least in 2 species of barnacles (Findlay et al. 2010a,b). However, sensitivity does appear to change with life-cycle stage, as shown in Hyas araneus, where one particular stage of development was identified as being the most vulnerable (Walther et al. 2010). Moreover, sensitivity of early life stages to a single environmental variable can change within species according to geographical distribution (Findlay et al. 2010b, Walther et al. 2010). One population can be more sensitive to $\mathrm{pCO}_{2}$, while the other is more sensitive to temperature (Walther et al. 2010). Although investigations into the combined effects of elevated $\mathrm{pCO}_{2}$ and temperature in crustaceans are few and far between, there has only been 1 study on the effects of elevated $\mathrm{pCO}_{2}$ and reduced salinity. This is surprising given the role of ion and acid-base homeostasis in the determination of a species' sensitivity to ocean acidification. In this particular study, the exposure of the intertidal amphipod Echinogammarus marinus to elevated $\mathrm{CO}_{2}(0.20 \mathrm{kPa})$ at 3 salinities $(10,22$ and 35 psu) had little effect on hatching success and developmental rate (Egilsdottir et al. 2009). Overall, reductions in salinity were found to be more important than elevations in $\mathrm{CO}_{2}$.

\section{CONCLUSIONS AND FUTURE DIRECTIONS}

The main purpose of the present review was to summarise our current understanding of the potential biological effects of ocean acidification on marine crustaceans and to identify and characterise those species or groups most at risk. The study of marine crustaceans can make a valuable contribution to ocean acidification research because crustaceans occupy a wide variety of aquatic habitats and show a range of tolerances to environmental change. As a result they demonstrate a range of responses that can be used to increase our understanding of the mechanisms that determine tolerances to ocean acidification, as well as clarify the subsequent long-term effects on performance and survival. The physiological studies carried out to date suggest that the most vulnerable groups are those that are unable to compensate for the changes imposed by elevated $\mathrm{pCO}_{2}$ and reduced $\mathrm{pH}$ levels. These species tend to be poor iono- and osmoregulators, living in lowenergy environments with low metabolic rates and low routine levels of activity, such as deep-sea and polar environments. From the limited data set, it appears that these species are characterised by low buffering capacities and a general inability to mobilise $\mathrm{HCO}_{3}^{-}$ ions from the seawater or from the exoskeleton to buffer the acid-base disturbances caused by ocean acidification. Moreover, they are highly specialised for living at low and stable temperatures and may be metabolically limited with respect to further change. Consequently the more vulnerable species are less likely to succeed in overcoming the combined effects of ocean acidification and increasing temperature or reduced salinity and $\mathrm{pO}_{2}$ levels resulting from climate change. In addition, they are less likely to be able to compete with warm-water invasive species that will be more adaptable and better able to exploit available resources. Crustacean species likely to be more tolerant of ocean acidification are those currently inhabiting fluctuating environments, such as estuaries and shallow coastal regions. These species are less likely to 
suffer long-term reductions in fitness because they have the capacity to compensate acid-base disturbances via ion exchange mechanisms. The exceptions are slow-moving crabs with poor haemolymphbuffering capacities. The latter may be more vulnerable to ocean acidification due to their limited capacity to adjust their acid-base physiology. Overall, we still have little idea of how these various species will cope during prolonged exposure to elevated $\mathrm{pCO}_{2}$ on a scale of months to years, or how multiple stressors will affect individual fitness. However, the indication is that concomitant changes in temperature, salinity and oxygen can have important synergistic effects.

Given the close association between physiological capacities and the ability to cope with ocean acidification, there is a continuing need to examine the mechanisms responsible for these compensatory responses. The relationship between ion regulation and acid-base balance is still far from clear. Even less is known about the mechanisms underlying calcification processes in crustaceans. All 3 physiological processes, i.e. iono-regulation, acid-base balance and calcification, could be linked via the mobilisation of $\mathrm{Ca}^{2+}$ and $\mathrm{HCO}_{3}{ }^{-}$from the exoskeleton (Whiteley 1999). In addition, it is unclear whether those species that can tolerate ocean acidification will be able to maintain compensatory responses over time, and whether less tolerant species will be able to acclimatise or even adapt to the changes in seawater carbonate chemistry. Future studies are needed to examine physiological and ecological responses to ocean acidification in crustacean species with differing tolerances to environmental change over longer time intervals at relevant $\mathrm{pCO}_{2}$ levels and in combination with changes in temperature, salinity, or oxygen levels. The resulting data can then be used to inform on the groups of crustaceans most likely to be adversely affected by ocean acidification and climate change. It can also be used to explain patterns of vulnerability in other marine taxa. In addition, it is vital that we increase our understanding of the capacity of marine crustaceans to adapt to the effects of ocean acidification. Such information will help towards forecasting the potential long-term effects of ocean acidification and climate change on marine ecosystems (Kurihara 2008). Even though a few multi-generation experiments have been conducted to date (Kurihara \& Ishimatsu 2008), many more are needed in order to examine the potential for adaption under future ocean acidification scenarios.

Currently, there is little evidence to suggest that early life stages are more vulnerable to ocean acidification than adults, but the data set is extremely limited. Recent work suggests that survival rates are affected and subtle changes in the ability to calcify the exoskeleton during growth by moulting may have long-term repercussions for survival and recruitment. From the 2 barnacle species studied to date, it appears that ocean acidification and climate change will not affect post-larval survival (Findlay et al. 2010a,b), but sensitivities can vary with stage of development (Walther et al. 2010). In addition, it has been shown that ocean acidification can affect growth rates and moulting frequencies in crustaceans (Kurihara et al. 2008, Dissanayake \& Ishimatsu 2011). Further work is needed to determine whether this is a general effect or whether it is species specific. If moulting frequencies and mortality rates in crustaceans are more generally affected by ocean acidification, this could have a profound effect on species survival, distribution and abundance. Overall, future studies are needed to identify any potential bottlenecks during development and to examine the combined effects of ocean acidification and other environmental variables on the survival of early life stages from crustacean species with differing tolerances to environmental change. Although marine crustaceans are currently considered to be broadly tolerant of ocean acidification, closer examination reveals that certain species and developmental stages could be adversely affected. It is important that the scientific community considers the impacts of ocean acidification and climate change on representatives from all marine invertebrate phyla in order to truly appreciate the resulting effects on species richness, community structure and function, and ecosystem processes.

Acknowledgements. This review was prepared as part of 2 research projects: Impacts of ocean acidification on key benthic ecosystems, UK Ocean Acidification Research Programme funded by DEFRA, NERC and DECC; and SUSFISH, a project funded by the European Regional Development Fund through the Ireland Wales Programme (INTERREG 4A).

\section{LITERATURE CITED}

Abrahamsson S (1972) Fecundity and growth of some populations of Astacus astacus Linne in Sweden. Rep Inst Freshw Res 52:23-37

Anger K (2001) The biology of decapod crustacean larvae. Crustacean Issues Vol 14, Balkema, Lisse

Arnold KE, Findlay HS, Spicer JI, Daniels CL, Boothroyd D (2009) Effect of $\mathrm{CO}_{2}$-related acidification on aspects of the larval development of the European lobster, Homarus gammarus (L.). Biogeosciences 6:1747-1754

Atkinson A, Siegel V, Pakhomov EA, Jessopp MJ, Loeb V (2009) A re-appraisal of the total biomass and annual production of Antarctic krill. Deep-Sea Res I 56:727-740

> Beniash E, Ivanina A, Lieb NS, Kurochkin I, Sokolova IM (2010) Elevated level of carbon dioxide affects metabolism and shell formation in oysters Crassostrea virginica. Mar Ecol Prog Ser 419:95-108

Boßelmann F, Romano P, Fabritius H, Raabe D, Epple M (2007) The composition of the exoskeleton of two crustaceans: the American lobster Homarus americanus and the edible crab Cancer pagurus. Thermochim Acta 463: $65-68$ 
Burnett LE (1997) The challenges of living in hypoxic and hypercapnic aquatic environments. Am Zool 37:633-640

Burnett LE, McMahon BR (1987) Gas-exchange, hemolymph acid-base status, and the role of branchial water stores during air exposure in three littoral crab species. Physiol Zool 60:27-36

> Caldeira K, Wickett ME (2003) Anthropogenic carbon and ocean $\mathrm{pH}$. Nature 425:365

Cameron JN (1978) Effects of hypercapnia on blood acid-base status, $\mathrm{NaCl}$ fluxes, and trans-gill potential in freshwater blue crabs, Callinectes sapidus. J Comp Physiol 123:137-141

Cameron JN (1985) Molting in the blue crab. Sci Am 252: 102-109

Cameron JN, Iwama GK (1987) Compensation of progressive hypercapnia in channel catfish and blue crabs. J Exp Biol 133:183-197

Cameron JN, Wood CM (1985) Apparent $\mathrm{H}^{+}$excretion and $\mathrm{CO}_{2}$ dynamics accompanying carapace mineralization in the blue crab (Callinectes sapidus) following molting. J Exp Biol 114:181-196

Dissanayake A, Ishimatsu A (2011) Synergistic effects of elevated $\mathrm{CO}_{2}$ and temperature on the metabolic scope and activity in a shallow-water coastal decapod (Metapenaeus joyneri; Crustacea: Penaeidae). ICES J Mar Sci. doi: 10.1093/icesjms/fsq188

Dissanayake A, Clough R, Spicer JI, Jones MB (2010) Effects of hypercapnia on acid-base balance and osmo-/ionoregulation in prawns (Decapod: Palaemonidae). Aquat Biol 11:27-36

> Doney SC, Fabry VJ, Feely RA, Kleypas JA (2009) Ocean acidification: the other $\mathrm{CO}_{2}$ problem. Annu Rev Mar Sci 1:169-192

> Dupont S, Havenhand J, Thorndike W, Peck L, Thorndike M (2008) $\mathrm{CO}_{2}$-driven ocean acidification radically affects larval survival and development in the brittle star Ophiothrix fragilis. Mar Ecol Prog Ser 373:285-294

> Dupont S, Ortega-Martinez O, Thorndyke M (2010) Impact of near-future ocean acidification on echinoderms. Ecotoxicology 19:449-462

Egilsdottir H, Spicer JI, Rundle SD (2009) The effect of $\mathrm{CO}_{2}$ acidified seawater and reduced salinity on aspects of the embryonic development of the amphipod Echinogammarus marinus (Leach). Mar Pollut Bull 58:1187-1191

Fabry VJ, Seibel BA, Feely RA, Orr JC (2008) Impacts of ocean acidification on marine fauna and ecosystem processes. ICES J Mar Sci 65:414-432

Feely RA, Sabine CL, Lee K, Berelson W, Kleypas J, Fabry VJ, Millero FJ (2004) Impact of anthropogenic $\mathrm{CO}_{2}$ on the $\mathrm{CaCO}_{3}$ system in the oceans. Science 305:362-366

Felten V, Charmantier G, Charmantier-Daures M, Aujoulat F, Garric J, Geffard O (2008) Physiological and behavioural responses of Gammarus pulex exposed to acid stress. Comp Biochem Physiol C 147:189-197

> Findlay HS, Kendall MA, Spicer JI, Widdicombe S (2009) Future high $\mathrm{CO}_{2}$ in the intertidal may compromise adult barnacle Semibalanus balanoides survival and embryonic development rate. Mar Ecol Prog Ser 389:193-202

Findlay HS, Kendall MA, Spicer JI, Widdicombe S (2010a) Post-larval development of two intertidal barnacles at elevated $\mathrm{CO}_{2}$ and temperature. Mar Biol 157:725-735

Findlay HS, Kendall MA, Spicer JI, Widdicombe S (2010b) Relative influence of ocean acidification and temperature on intertidal post-larvae at the northern edge of their geographic distribution. Estuar Coast Shelf Sci 86:675-682

Freire CA, Onken H, McNamara JC (2008) A structurefunction analysis of ion transport in crustacean gills and excretory organs. Comp Biochem Physiol A 151:272-304 Gaillard S, Malan A (1983) Intracellular pH regulation in response to ambient hyperoxia or hypercapnia in the crayfish. Mol Physiol 4:231-243

Gattuso JP, Frankignoulle M, Bourge I, Romaine S, Buddemeier RW (1998) Effect of calcium carbonate saturation of seawater on coral calcification. Global Planet Change 18:37-46

Gazeau F, Quiblier C, Jansen JM, Gattuso JP, Middelburg JJ, Heip CHR (2007) Impact of elevated $\mathrm{CO}_{2}$ on shellfish calcification. Geophys Res Lett 34:L07603 doi: 10.1029/ 2006GL08554

Gilles R (1983) Volume maintenance and regulation in animal cells-some features and trends. Mol Physiol 4:3-16

Guinotte JM, Fabry VJ (2008) Ocean acidification and its potential effects on marine ecosystems. Ann N Y Acad Sci 1134:320-342

Hale R, Calosi P, McNeil L, Mieszkowska N, Widdicombe S (2011) Predicted levels of future ocean acidification and temperature rise could alter community structure and biodiversity in marine benthic communities. Oikos 120: 661-674

> Hauton C, Tyrrell T, Williams J (2009) The subtle effects of seawater acidification on the amphipod Gammarus locusta. Biogeosciences 6:1479-1489

Henry RP, Cameron JN (1982) Acid-base balance in Callinectes sapidus during acclimation from high to low salinity. J Exp Biol 101:255-264

Houghton JT, Ding Y, Griggs DJ, Noguer M, van der Linden PJ, Xiaosu D (2001) Climate change 2001: the scientific basis. Contribution of Working Group I to the Third Assessment Report of the Intergovernmental Panel on Climate Change. Cambridge University Press, Cambridge

Intanai I, Taylor EW, Whiteley NM (2009) Effects of salinity on rates of protein synthesis and oxygen uptake in the postlarvae and juveniles of the tropical prawn Macrobrachium rosenbergii (de Man). Comp Biochem Physiol A 152: 372-378

> Jokumsen A, Wells RMG, Ellerton HD, Weber RE (1981) Hemocyanin of the giant Antarctic isopod, Glyptonotus antarcticus: structure and effects of temperature and $\mathrm{pH}$ on its oxygen affinity. Comp Biochem Physiol A 70:91-95

Kleypas JA, Feeley RA, Fabry VJ, Langdon C, Sabine CL, Robbins LL (2006) Impacts of ocean acidification on coral reefs and other marine calcifiers: a guide for future research. In: Report of a workshop held 18-20 April, 2005, St. Petersburg, Florida sponsored by the NSF, NOAA and the US Geological Survey

Knoll A, Bambach RK, Payne JL, Pruss S, Fischer WW (2007) Paleophysiology and end-Permian mass extinction. Earth Planet Sci Lett 256:295-313

Kurihara $\mathrm{H}$ (2008) Effects of $\mathrm{CO}_{2}$-driven ocean acidification on the early developmental stages of invertebrates. Mar Ecol Prog Ser 373:275-284

Kurihara H, Ishimatsu A (2008) Effects of high $\mathrm{CO}_{2}$ seawater on the copepod (Acartia tsuensis) through all life stages and subsequent generations. Mar Pollut Bull 56:1086-1090

Kurihara H, Shimode S, Shirayama Y (2004a) Sub-lethal effects of elevated concentration of $\mathrm{CO}_{2}$ on planktonic copepods and sea urchins. J Oceanogr 60:743-750

> Kurihara H, Shimode S, Shirayama Y (2004b) Effects of raised $\mathrm{CO}_{2}$ concentration on the egg production rate and early development of two marine copepods (Acartia steueri and Acartia erythraea). Mar Pollut Bull 49:721-727

Kurihara H, Matsui M, Furukawa H, Hayashi M, Ishimatsu A (2008) Long-term effects of predicted future seawater $\mathrm{CO}_{2}$ conditions on the survival and growth of the marine 
shrimp Palaemon pacificus. J Exp Mar Biol Ecol 367:41-46 Langdon C, Takahashi T, Sweeney C, Chipman D and others (2000) Effects of calcium carbonate state on the calcification rate of an experimental coral reef. Global Biogeochem Cycles 14:639-654

Langenbuch M, Pörtner HO (2002) Changes in metabolic rate and $\mathrm{N}$ excretion in the marine invertebrate Sipunculus nudus under conditions of environmental hypercapnia: identifying effective acid-base variables. J Exp Biol 205: $1153-1160$

Langenbuch M, Pörtner HO (2003) Energy budget of hepatocytes from Antarctic fish (Pachycara brachycephalum and Lepidonotothen kempi) as a function of ambient $\mathrm{CO}_{2}$ : $\mathrm{pH}-$ dependent limitations of cellular protein biosynthesis? J Exp Biol 206:3895-3903

Leong P, Manahan DT (1997) Metabolic importance of $\mathrm{Na}^{+} / \mathrm{K}^{+}$-ATPase activity during sea urchin development. J Exp Biol 200:2881-2892

Martin JW, Davis GE (2001) An updated classification of the recent Crustacea. Science Series 39, Natural History Museum, Los Angeles, CA

> Martin JW, Davis GE (2006) Historical trends in crustacean systematics. Crustaceana 79:1347-1368

- Mayor DJ, Matthews C, Cook K, Zuur AF, Hay S (2007) $\mathrm{CO}_{2}$ induced acidification affects hatching success in Calanus finmarchicus. Mar Ecol Prog Ser 350:91-97

McDonald MR, McClintock JB, Amsler CD, Rittschof D, Angus RA, Orihuela B, Lutostanski K (2009) Effects of ocean acidification over the life history of the barnacle Amphibalanus amphitrite. Mar Ecol Prog Ser 385:179-187

McMahon BR, Stuart SA (1989) Physiological problems of crayfish in acid waters. In: Morris R, Taylor EW, Brown DJA, Brown JA (eds) Acid toxicity and aquatic animals. SEB Seminar Series 34, Cambridge University Press, Cambridge, p 171-199

McNamara JC, Moreira GS (1987) $\mathrm{O}_{2}$ consumption and acute salinity exposure in the fresh-water shrimp Macrobrachium olfersii (Wiegmann) (Crustacea, Decapoda): whole animal and tissue respiration. J Exp Mar Biol Ecol 113:221-230

Melzner F, Gutowska MA, Langenbuch M, Dupont S and others (2009) Physiological basis for high $\mathrm{CO}_{2}$ tolerance in marine ectothermic animals: pre-adaptation through lifestyle and ontogeny? Biogeosciences 6:2313-2331

Metzger R, Sartoris FJ, Langenbuch M, Pörtner HO (2007) Influence of elevated $\mathrm{CO}_{2}$ concentrations on thermal tolerance of the edible crab Cancer pagurus. J Therm Biol 32:144-151

Michaelidis B, Ouzounis C, Paleras A, Pörtner HO (2005) Effects of long-term moderate hypercapnia on acid-base balance and growth rate in marine mussels Mytilus galloprovincialis. Mar Ecol Prog Ser 293:109-118

- Miles H, Widdicombe S, Spicer JI, Hall-Spencer J (2007) Effects of anthropogenic seawater acidification on acidbase balance in the sea urchin Psammechinus miliaris. Mar Pollut Bull 54:89-96

> Moreira GS, McNamara JC, Shumway SE, Moreira PS (1983) Osmoregulation and respiratory metabolism in Brazilian Macrobrachium (Decapoda, Palaemonidae). Comp Biochem Physiol A 74:57-62

Morris S, Taylor AC (1983) Diurnal and seasonal variation in physicochemical conditions within intertidal rock pools. Estuar Coast Shelf Sci 17:339-355

> Neues F, Ziegler A, Epple M (2007) The composition of the mineralized cuticle in marine and terrestrial isopods: a comparative study. CrystEngComm 9:1245-1251

Neufield DS, Cameron JN (1992) Postmoult uptake of calcium by the blue crab (Callinectes sapidus) in water of low salinity. J Exp Biol 171:283-299

Onken H, Putzenlechner M (1995) A V-ATPase drives active, electrogenic and $\mathrm{Na}+$-independent $\mathrm{Cl}^{-}$absorption across the gills of Eriocheir sinensis. J Exp Biol 198:767-774

Orr JC, Fabry VJ, Aumont O, Bopp L and others (2005) Anthropogenic ocean acidification over the twenty-first century and its impact on calcifying organisms. Nature 437:681-686

Pane EF, Barry JP (2007) Extracellular acid-base regulation during short-term hypercapnia is effective in a shallowwater crab, but ineffective in a deep-sea crab. Mar Ecol Prog Ser 334:1-9

> Pannevis MC, Houlihan DF (1992) The energetic cost of protein synthesis in isolated hepatocytes of rainbow trout (Oncorhynchus mykiss). J Comp Physiol B 162:393-400

Peck LS (2002) Ecophysiology of Antarctic marine ectotherms: limits to life. Polar Biol 25:31-40

Péqueux A (1995) Osmotic regulation in crustaceans. J Crustac Biol 15:1-60

Pörtner HO (2002) Climate variations and the physiological basis of temperature dependent biogeography: systemic to molecular hierarchy of thermal tolerance in animals. Comp Biochem Physiol A 132:739-761

Pörtner HO (2008) Ecosystem effects of ocean acidification in times of ocean warming: a physiologist's view. Mar Ecol Prog Ser 373:203-217

Pörtner HO (2010) Oxygen- and capacity-limitation of thermal tolerance: a matrix for integrating climate-related stressor effects in marine ecosystems. J Exp Biol 213: 881-893

Pörtner HO, Farrell AP (2008) Physiology and climate change. Science 322:690-691

> Pörtner HO, Reipschläger A, Heisler N (1998) Acid-base regulation, metabolism and energetics in Sipunculus nudus as a function of ambient carbon dioxide. J Exp Biol 201: $43-55$

> Pörtner HO, Bock C, Reipschläger A (2000) Modulation of the cost of pHi regulation during metabolic depression: a ${ }^{31} \mathrm{P}-$ NMR study in invertebrate (Sipunculus nudus) isolated muscle. J Exp Biol 203:2417-2428

Pörtner HO, Langenbuch M, Reipschläger A (2004) Biological impact of elevated ocean $\mathrm{CO}_{2}$ concentrations: lessons from animal physiology and earth history. J Oceanogr 60: 705-718

Pörtner HO, Langenbuch M, Michaelidis B (2005) Synergistic effects of temperature extremes, hypoxia and increases in $\mathrm{CO}_{2}$ on marine animals: from Earth history to global change. J Geophys Res 110:1-15

Pörtner HO, Peck L, Somero G (2007) Thermal limits and adaptation in marine Antarctic ectotherms: an integrative view. Philos Trans R Soc B 362:2233-2258

Przeslawski R, Ahyong S, Byrne M, Worheide G, Hutchings P (2008) Beyond corals and fish: the effects of climate change on non-coral benthic invertebrates of tropical reefs. Glob Change Biol 14:2773-2795

Ries JB, Cohen AL, McCorkle DC (2009) Marine calcifiers exhibit mixed responses to $\mathrm{CO}_{2}$-induced ocean acidification. Geology 37:1131-1134

Rosa R, Seibel BA (2008) Synergistic effects of climate-related variables suggest future physiological impairment in a top oceanic predator. Proc Natl Acad Sci USA 105:20776-20780

Royal Society Report (2005) Ocean acidification due to increasing atmospheric carbon dioxide. Policy Document 12/05, The Royal Society, London

> Santos LCF, Belli NM, Augusto A, Masui DC, Leone FA, McNamara JC, Furriel RPM (2007) Gill $\left(\mathrm{Na}^{+}, \mathrm{K}^{+}\right)$-ATPase 
in diadromous, freshwater palaemonid shrimps: speciesspecific kinetic characteristics and alpha-subunit expression. Comp Biochem Physiol A 148:178-188

Small D, Calosi P, White D, Spicer JI, Widdicombe S (2010) Impact of medium-term exposure to $\mathrm{CO}_{2}$ enriched seawater on the physiological functions of the velvet swimming crab Necora puber. Aquat Biol 10:11-21

Somero GN (2002) Thermal physiology and vertical zonation of intertidal animals: optima, limits, and costs of living. Integr Comp Biol 42:780-789

Spicer JI, Raffo A, Widdicombe S (2007) Influence of $\mathrm{CO}_{2}-$ related seawater acidification on extracellular acid-base balance in the velvet swimming crab Necora puber. Mar Biol 151:1117-1125

Taylor EW, Taylor HH (1992) Gills and lungs: the exchange of gases and ions. In: Harrison FW, Humes AG (eds) Microscopic anatomy of invertebrates, Vol 10. Wiley-Liss, New York, NY, p 203-293

Taylor EW, Whiteley NM (1989) Oxygen transport and acid-base balance in the haemolymph of the lobster, Homarus gammarus, during aerial exposure and resubmersion. J Exp Biol 144:417-436

Towle DW, Kays WT (1986) Basolateral localization of $\mathrm{Na}^{+} / \mathrm{K}^{+}$ATPase in gill epithelium of two osmoregulating crabs, Callinectes sapidus and Carcinus maenas. J Exp Zool 239: 311-318

Truchot JP (1975) Effect of hypercapnia on acid-base status of blood in crab Carcinus maenas (L) (CrustaceaDecapoda). CR Hebd Seances Acad Sci Paris Ser D 280: 311-314

Truchot JP (1980) Lactate increases the affinity of crab haemocyanin. J Exp Zool 214:205-208

Truchot JP (1981) The effect of water salinity and acid-base state on the blood acid-base balance in the euryhaline crab, Carcinus maenas (L). Comp Biochem Physiol A 68: 555-561

Truchot JP (1984) Water carbonate alkalinity as a determinant of haemolymph acid-base balance in the shore crab Carcinus maenas - a study at two different ambient $\mathrm{PCO}_{2}$ and $\mathrm{PO}_{2}$ levels. J Comp Physiol B 154:601-606

Truchot JP (1986) Changes in the haemolymph acid-base state of the shore crab, Carcinus maenas, exposed to simulated tidepool conditions. Biol Bull 170:506-518

Truchot JP (1992) Acid-base changes on transfer between seawater and fresh-water in the Chinese crab, Eriocheir sinensis. Respir Physiol 87:419-427

Truchot JP, Duhamel Jouve A (1980) Oxygen and carbon dioxide in the marine inter-tidal environment: diurnal and tidal changes in rock pools. Respir Physiol 39:241-254

Walther K, Sartoris FJ, Bock C, Pörtner HO (2009) Impact of anthropogenic ocean acidification on thermal tolerance of the spider crab Hyas araneus. Biogeosciences 6:2207-2215

Submitted: November 29, 2010; Accepted: April 28, 2011
Walther K, Anger K, Pörtner HO (2010) Effects of ocean acidification and warming on the larval development of the spider crab Hyas araneus from different latitudes (54 ${ }^{\circ}$ vs. $79^{\circ}$ N). Mar Ecol Prog Ser 417:159-170

> Wang WN, Wang AL, Bao L, Wang JP, Liu Y, Sun RY (2004) Changes of protein-bound and free amino acids in the muscle of the freshwater prawn Macrobrachium nipponense in different salinities. Aquaculture 233:561-571

Watt AJS, Whiteley NM, Taylor EW (1999) An in situ study of respiratory variables in three British sublittoral crabs with different routine rates of activity. J Exp Mar Biol Ecol 239: $1-21$

Weber AK, Pirow R (2009) Physiological responses of Daphnia pulex to acid stress. BMC Physiol 9:9

Wheatly MG (1997) Crustacean models for studying calcium transport: the journey from whole organisms to molecular mechanisms. J Mar Biol Assoc UK 77:107-125

> Wheatly MG, Henry RP (1992) Extracellular and intracellular acid-base regulation in crustaceans. J Exp Zool 263: $127-142$

Whiteley NM (1999) Acid-base regulation in aquatic crustaceans: role of bicarbonate ions. In: Egginton S, Taylor EW, Raven JA (eds) Regulation of acid-base status in animals and plants. SEB Seminar Series 68, Cambridge University Press, Cambridge, p 233-255

Whiteley NM, Taylor EW (1992) Oxygen and acid-base disturbances in the haemolymph of the lobster Homarus gammarus during commercial transport and storage. J Crustac Biol 12:19-30

Whiteley NM, Taylor EW, Clarke A, El Haj AJ (1997) Haemolymph oxygen transport and acid-base status in Glyptonotus antarcticus Eights. Polar Biol 18:10-15

Whiteley NM, Scott JL, Breeze SJ, McCann L (2001) Effects of water salinity on acid-base balance in decapod crustaceans. J Exp Biol 204:1003-1011

- Wickins JF (1984) The effect of hypercapnic seawater on growth and mineralization in penaeid prawns. Aquaculture 41:37-48

> Widdicombe S, Dashfield SL, NcNeill CL, Needham HR and others (2009) Effects of induced seawater acidification on infaunal diversity and sediment nutrient fluxes. Mar Ecol Prog Ser 379:59-75

> Widdicombe S, Spicer JI (2008) Predicting the impact of ocean acidification on benthic biodiversity: What can animal physiology tell us? J Exp Mar Biol Ecol 366:187-197

Wood CM, Cameron JN (1985) Temperature and the physiology of intracellular and extracellular acid-base regulation in the blue crab Callinectes sapidus. J Exp Biol 114: 151-179

> Wood HL, Spicer JI, Widdicombe S (2008) Ocean acidification may increase calcification rates, but at a cost. Proc Biol Sci 275:1767-1773

Proofs received from author(s): May 13, 2011 